\title{
Mineralogical and Geochemical Characteristics of the Sangarédi Bauxite Deposit, Boké Region, Republic of Guinea
}

\author{
Abdourahamane D. Barry ${ }^{1 *}$, Mamady Cissé $^{2}$, Mupenge M. Parfait ${ }^{1,3}$, Mallam M. Hallarou ${ }^{4}$ \\ ${ }^{1}$ Department of Geology, Pan African University Life and Earth Sciences Institute (PAULESI), University of Ibadan, Ibadan \\ P.O. Box 200284, Nigeria \\ ${ }^{2}$ Department of geology, Institute of Mining and Geology of Boké, P.O. Box 84 Boké, Republic of Guinea \\ ${ }^{3}$ Department of Geology, University of Bukavu, P.O. Box 162 Bukavu, Democratic Republic of Congo \\ ${ }^{4}$ Underground Water and Georessources Laboratory, Department of Geology, Faculty of Sciences and Techniques, Abdou \\ Moumouni University of Niamey, P.O. Box 10662 Niamey, Niger
}

Corresponding Author Email: abdourahmanediogobarry@gmail.com

https://doi.org/10.18280/eesrj.080102

Received: 20 December 2020

Accepted: 14 February 2021

\section{Keywords:}

Sangarédi-Guinea, sediment hosted, bauxite deposit, facies, laterite bauxite, chimogen bauxite

\begin{abstract}
Sangarédi is one of the few areas in the Republic of Guinea with confirmed bauxite deposits. Sangarédi deposit, which was formed by deep weathering of sedimentary and igneous rocks, is located at $11^{\circ} 5^{\prime} 23^{\prime \prime} \mathrm{N}$ and $13^{\circ} 46^{\prime} 46^{\prime \prime} \mathrm{W}$ in the eastern Boké region where it crops out over an area of about $10 \mathrm{~km}^{2}$. In this study, mineralogical and geochemical studies of Sangarédi deposit were done by using the X-ray diffractometry (XRD) and Inductively Coupled Plasma Atomic Emission Spectrometry (ICP-AES) methods. The mineralogical analyses show that gibbsite and boehmite are the dominant minerals in all of the bauxites, with average concentrations of $91.85 \%$ and $3.3 \%$, respectively. Goethite is the major iron mineral, with an average concentration of $1.35 \%$. whereas hematite makes up average of $0.7 \%$. Diaspore, dawsonite, rutile and anatase occur in low abundances $(<1 \%)$. Geochemical analyses of the bauxite samples show some significant differences in $\mathrm{Al}_{2} \mathrm{O}_{3}(55.63-68.92 \%), \mathrm{Fe}_{2} \mathrm{O}_{3}$ (1.44-8.89\%), $\mathrm{SiO}_{2}(0.47-5.68 \%)$, and $\mathrm{TiO}_{2}$ $(2.48-5.45 \%)$. Regardless of their parental rocks, the Sangarédi bauxites have very similar chemical compositions, with high aluminium, but low silica and iron contents, which distinguish them from other deposits in Guinea and many other parts the world.
\end{abstract}

\section{INTRODUCTION}

The Republic of Guinea hosts the largest bauxite reserve in the world, estimated to be about 40 billion tons [1]. The Sangarédi deposit, located between $11^{\circ} 5^{\prime} 23^{\prime \prime} \mathrm{N}$ and $13^{\circ} 46^{\prime} 46^{\prime \prime}$ $\mathrm{W}$ in the Boké region, crops out over an area of $\sim 10 \mathrm{~km}^{2}$. It is located on the Sangarédi plateau at an elevation of $280 \mathrm{~m}$. Although the precise age of the deposit is unknown, Bushinskiy [2] suggested that it was formed in Oligo-Miocene time. Schmidt [3] proposed that the parent rock of the Sangarédi bauxite was dolerite although both sandstone and schist are also present in the region. In contrast, Akayemov [4] concluded, on the basis of rounded pebbles and grains of gibbsite and bedding in some deposits, that the Sangarédi bauxites were, derived chiefly from a sedimentary precursor. He suggested that these sediments were deposited in lakes and coastal alluvial environments in the middle Miocene. Such an origin may explain their high $\mathrm{Al}_{2} \mathrm{O}_{3}$ contents and high grade and uncommon thicknesses [5]. A geochemical study of the Sangarédi deposit by Mamedov et al. [6] identified three genetic types of bauxite; (i) in situ lateritic bauxite, (ii) sedimentary and (iii) infiltration metasomatic (geliform aphanitic and oolitic) bauxite, locally termed "chimogen", a name applied by geologists of the Compagnie des Bauxites de Guinée (CBG) for deposits that had undergone secondary recrystallization and chemical modification leading to significant enrichment in $\mathrm{Al}_{2} \mathrm{O}_{3}$. A somewhat later study by
Zhang et al. [7], identified a wider range of parental rocks in the Boké-Sangarédi area, including Palaeozoic metasedimentary and magmatic rocks, as well as Cenozoic sediments. Although the Sangarédi deposit is well known in Guinea, there is little detailed information on the nature of the host rocks, the age of the deposit, the mineralization processes by which it was formed and its economic potential.

This work is aimed at integrating new and literature data on the mineralogy, petrography and geochemistry of the Sangarédi deposit that will provide a basis for comparison with other bauxite deposits in Guinea and other countries.

The remainder of this paper is organized as follows apart the introduction: Section 2 introduces the geological setting with regard to the regional and local geology of the study are, Section 3 describes the material and method used, the section 4 presents the result, section 5 highly the discussion results and section 6 includes the conclusion and recommendation.

\section{GEOLOGICAL SETTING}

\subsection{Regional geology}

Africa is composed of Precambrian basement overlain by Palaeozoic-Cenozoic strata [7]. More than the half of the continent is covered with Precambrian strata that have undergone varying degrees of metamorphism, migmatization 
and granitization. The oldest parts of the Precambrian basement are composed of four cratons; i.e., West Africa Craton (WAC), Zaire or Central Africa Craton, West Nile Craton and South Africa Craton [7, 8].

The Republic of Guinea lies in the West Africa Craton, in the north western part of Africa. The region is dominated by an Archean metamorphic series with a migmatitic granitegreenstone belt in the central part. However, in the western part a late Palaeozoic sequence near the Atlantic Ocean is covered by Cenozoic deposits [7]. The Sangarédi district consists of upper Proterozoic basement overlain by marine sedimentary rocks and volcanic deposits of Palaeozoic age [7].

The study area in the northwestern part of Guinea is characterized by Palaeozoic (Figure 1) deposits, including sedimentary strata of the Pita suite (Ordovician), Télimélé suite (Silurian), and Faro Suite (Devonian). Fundamentally, in the study area (Figure 1), the Pita suite is represented by quartz sandstone, pebble conglomerate and conglomerate, the Télimélé suite by argillites, siltstones and shales, and the Faro suite by siltstones, argillites and fine-grained sandstones $[1,9]$.

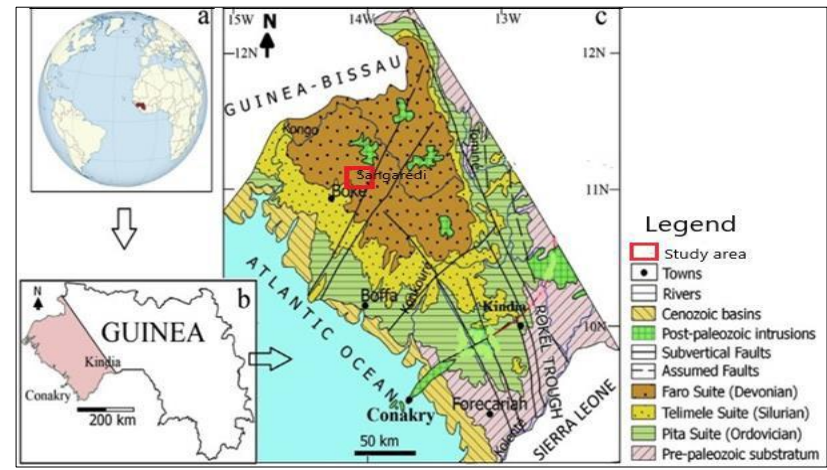

Figure 1. (a, b, c) Location of the study area on the Geologic and tectonic map $[1,9,10]$

\subsection{Local Geology of the Sangarédi bauxite deposits}

The Sangarédi area is located in northwestern Guinea along the left bank of the middle and upper Cogon River. It lies along the axial zone of the Bove Syncline, which exposes Ordovician, Silurian, and Devonian sedimentary deposits and Mesozoic mafic trap rocks [1, 9]. Most of the bauxite deposits in the Sangarédi district rest on weathered schist and sandstone of Devonian or post-Devonian age, which in turn, rest on relatively fresh cordierite hornfels [3]. Many of the deposits have three distinct layers in the bauxites; an upper zone which is 8.7-13 m thick, consisting of alternating layers and lenses of poorly sorted rounded grains and pebbles of bauxite, a middle segment, 8-19.5 m thick, of fairly well-sorted gravelly bauxite, and a basal zone $2.5-13 \mathrm{~m}$ thick that consists of interbedded gravelly and clayey bauxite. The lower segment rests with a sharp contact on Silurian siltstone [4]. Others, particularly those derived from dolerites, lack such clear zones.

\section{MATERIALS AND METHODOLOGY}

\subsection{Sampling}

The bauxites were logged and sampled along transects through the study area. Profiles in mining pits were carefully logged, with emphasis on the rock types, structures, and mineral contents. Representative samples were collected both from fresh surface outcrops and mining pits which varied in depth between 8 and $12 \mathrm{~m}$. The bauxite samples were collected based on their color, structure and location within the study area (see Figure 2).

Samples E09, E11, E13 and E16 are in-situ lateritic bauxites. Samples E09 and E13 are brown, Sample E11 is brownish grey, whereas E16 is violet-like in colour. Sample E11, which has and, whereas formed on Palaeozoic argillites, whereas the other three, which have hard, porous textures, were derived from dolerite. Samples E01, E02, E04, E08 and E17 were all derived from sedimentary sequences. bauxites, E01 and E08 are brownish grey in colour and are gravelly in texture. E02 and E17 are brownish yellow to white and have conglomeratic textures. E04 is light yellow to white with a psammitic texture. Samples E05, E10, E15 are chimogen bauxites. E05 is white and has oolitic texture, whereas E10 is yellow to grey in colour, with a pisolitic in texture. E15 is yellow in colour. The chimogen bauxites do not retain the textures of their parental rocks.

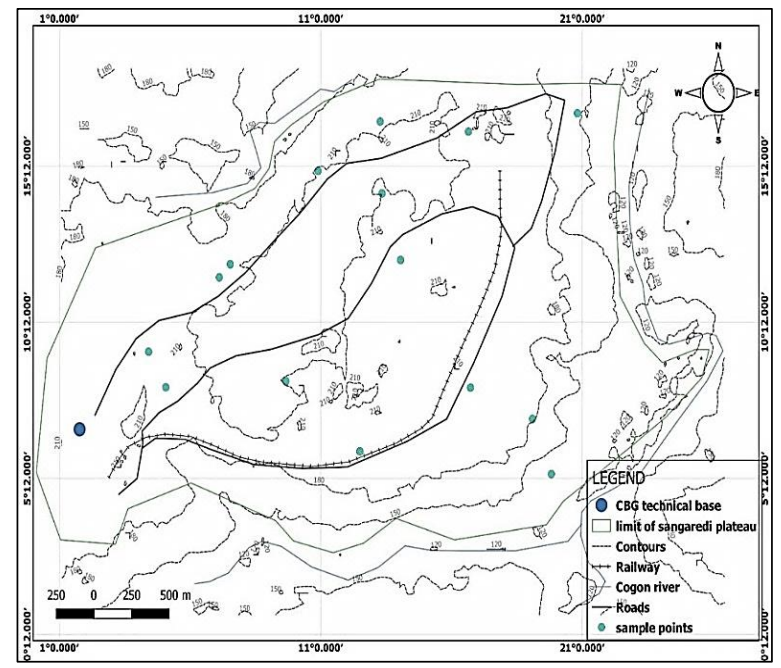

Figure 2. Topographical map of the study area showing sampling locations (Contours are in meters)

\subsection{Thin section and mineralogical analyses}

Thin sections were prepared from six sample and examined for their texture and mineralogy. Fourteen samples were then crushed to pass an <80-micron sieve. All equipment was carefully cleaned between preparation of each sample.

The prepared samples were analyzed using the X-ray diffractometry (XRD) method. Two representative samples from different types of bauxite were analyzed to determine the nature and abundance of the clay minerals associated with the different types of bauxite at ACME Laboratories, Vancouver, Canada. In addition, four representative samples of bauxite were analyzed by XRD at the NGRL laboratory, Kadouna, Nigeria to identify the dominant minerals. The samples were reduced to the optimum grain-size range for quantitative $\mathrm{X}$-ray analysis $(<10 \mu \mathrm{m})$ by grinding under ethanol in a vibratory McCrone Micronizing Mill for 10 minutes. Continuous-scan $\mathrm{X}$-ray powder-diffraction data were collected over a range 3$80^{\circ} 2$ with $\mathrm{CoK} \alpha$ radiation on a Bruker D8 Advance BraggBrentano diffractometer equipped with an Fe filter foil, 0.6 $\mathrm{mm}\left(0.3^{\circ}\right)$ divergence slit, incident- and diffracted-beam Soller slits and a LynxEye-XE detector. The long fine-focus Co Xray tube was operated at $35 \mathrm{kV}$ and $40 \mathrm{~mA}$, using a take-off angle of $6^{\circ}$. 


\subsection{Geochemical analyses}

The prepared samples were analyzed using the Inductively Coupled Plasma Atomic Emission Spectrometry (ICP-AES). Twelve (12) representative samples were analyzed for major, trace and rare earth Elements (REE) using the (ICP-AES) at the ACME laboratories, Vancouver, Canada.

\section{RESULTS AND DISCUSSIONS}

\subsection{Lithological characteristics of the bauxite}

\subsubsection{Sediment-hosted and chimogen bauxite profiles}

The lithology of the sediment-hosted and chimogen bauxite profiles in the Sangarédi deposit is generally, from the surface down topsoil, bauxite, clayey sand and sandstone (Figure 3a). The thicknesses of top soil zones range from 0.2 to $1 \mathrm{~m}$, whereas the sediment-hosted bauxite zones are 4 to $8 \mathrm{~m}$ of thick, and clayey zones are 11-16 m thick (Figure 3a). Megascopically, the bauxite typically ranges from gravelly at the top, passing downward into conglomeritic and finally to psammitic. Most of the bauxite is reddish brown, likely due to the presence of hematite and other iron oxides. The topsoil is loamy, and dark grey in colour, whereas the basal clayey zone is white to grey. Where present, preserved structures and textures of the bauxites make it possible to deduce the primary lithologies Sediment-hosted and chimogen bauxites are in direct contact with the basal clay (Figure 3a).

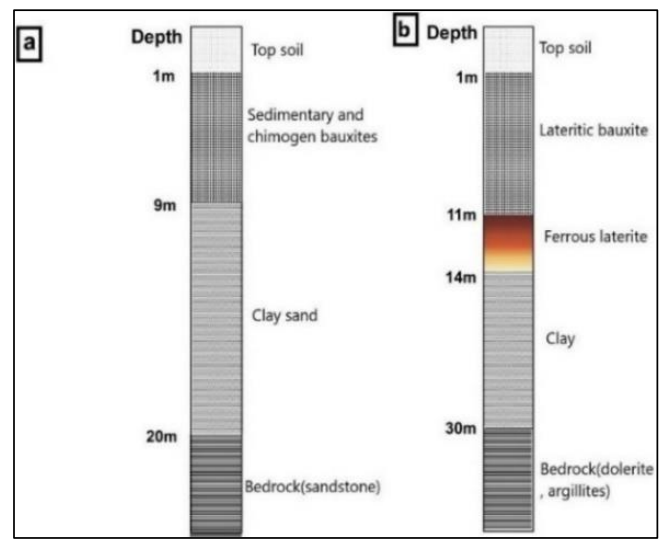

Figure 3. Generalised geological sections of the Sangarédi bauxite deposits; (a) sediment-hosted and chimogen bauxite profile; (b) lateritic bauxite profile

\subsubsection{Lateritic bauxite profiles}

The lateritic in-situ bauxite profiles consist generally of a succession of zones comprising a topsoil zone, lateritic bauxite zone, laterite zone, clay zone and bedrock (Figure 3b). The top soil is generally dark grey in colour but the bauxites are mostly reddish-brown. The lateritic bauxites are generally mediumgrained, but they have variable textures generally reflecting the bedrock textures. The clay zone at the base is fine grained in and white to grey in colour. During the field work, argillite outcrops were identified in the southwest and western part of the Sangarédi plateau (Figure 4c), whereas dolerite was identified in the eastern part, along the Cogon river (Figure 2). the bedrock textures.

The clay zone at the base is fine grained in and white to grey in colour. In-situ lateritic bauxite formed from argillite has a topsoil layer directly followed by laterite layer, averaging 10-
$12 \mathrm{~m}$. In-situ lateritic bauxites formed by alteration of the dolerites, have a very complex profiles with an average thickness of 16 to $17 \mathrm{~m}$. At a depth of $6 \mathrm{~m}$ below in the bauxite profile, there appears an alternation of white, grey and brown clay that passed downward to the partially weathered host rock (Figure 4b).

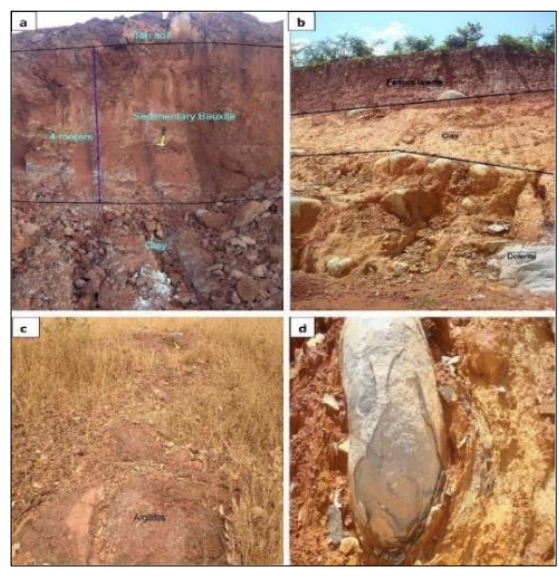

Figure 4. Field pictures: a) Sediment-hosted bauxite profile showing topsoil, bauxite and clay layers; b) Profile of a ferrous bauxite overlying a clay zone developed on altered dolerite; c) Outcrop of silurian argillites; d) Field photograph of incompletely altered dolerite

\subsection{Petrographic studies}

The bauxites and related laterites have a wide variety of textures and structures. The Sangarédi deposit is mainly composed of sediment-hosted bauxite with gravelly, conglomeratic skeletal, psammitic, and clayey facies. On the basis of our field and macroscopic studies we recognize three genetic types of bauxite in this deposit:

Sediment-hosted bauxites with detrital structures and textures ranging from conglomeratic to gravelly and pelitic bands and lenses. The structures and textures in these bauxites were inherited from the original sediments from which they were formed.

Lateritic bauxites, which were derived directly from in-situ basement rocks including argillites and dolerites. These bauxites also inherited their textures and structures of their parental rocks.

- Chimogen bauxites, which were formed by postdepositional processes leading to enrichment of alumina preexisting sedimentary or in-situ lateritic deposits.

\subsubsection{Sediment-hosted bauxites}

Sediment-hosted bauxites in the Sangarédi deposit were formed by weathering of sedimentary deposits accumulated in the Paléo - Cogon lake basin during the Middle Miocene [6]. At that time, the Sangarédi area, was a deep-sea basin in which a variety of sediments accumulated. Following uplift of the basin, erosion removed a large part of these deposits. Thus, exposed to the surface, at an elevation of $240-260 \mathrm{~m}$, these sediments began to disintegrate and deteriorate and finally became bauxite. This type of bauxite preserves many features that show it was derived from the accumulated sediments. These bauxites are porous, pinkish- to reddish-brown in colour and characterized by irregular textures, ranging from gravelly (Figure 5a) to conglomeritic (Figure 5b), silty (Figure 5c) and psammitic (Figure 5d). Thin sections of these bauxites reveal 
an abundance of gibbsite (Figure 6). The gibbsite grains are whitish-blue color to grey in reflected light with weak pleochroism and moderate relief in plane polarized light. The gibbsite is accompanied by lesser amounts of goethite, which was identified by its opaque character, sub-vitreous luster, pale brown colour and imperfect cleavage.

A few grains of boehmite are also present, some of which have reddish-brown rims of goethite. Hematite is also relatively abundant. Quartz and kaolinite fill the pores and cracks in the sediment-hosted bauxites.

In-situ lateritic bauxite formed from argillite has a topsoil layer directly followed by laterite layer, averaging 10-12 m. Insitu lateritic bauxites formed by alteration of the dolerites, have a very complex profiles with an average thickness of 16 to 17 $\mathrm{m}$. At a depth of $6 \mathrm{~m}$ below in the bauxite profile, there appears an alternation of white, grey and brown clay that passed downward to the partially weathered host rock (Figure $4 b$ ).

\subsubsection{Lateritic bauxites (in-situ)}

Lateritic bauxites formed after alteration of basement rocks in the plateau, which are argillite and dolerite. The argillite

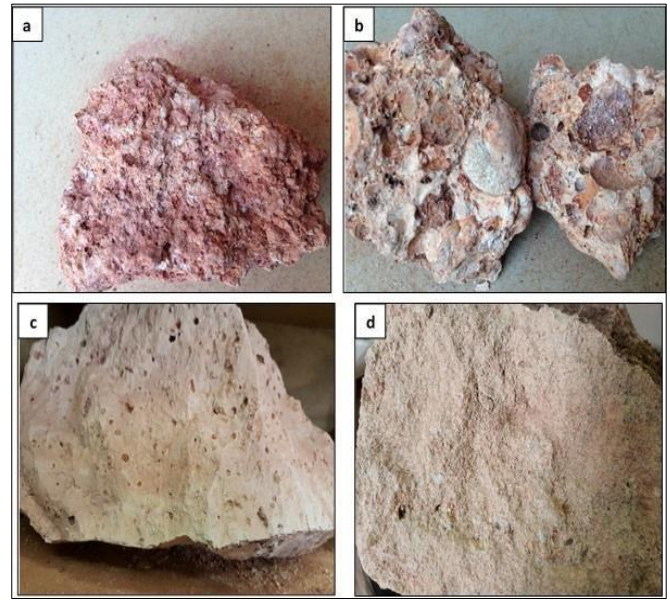

Figure 5. Photographs showing: (a) gravelly bauxite; b) conglomeratic bauxite; c) silty bauxite, and d) psammitic bauxite, all derived from sediment-hosted deposits

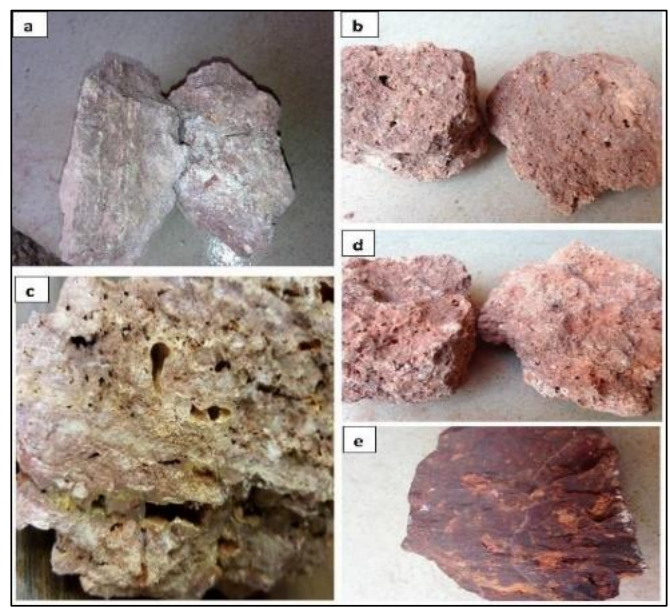

Figure 7. Photographs showing various features of the Sangarédi bauxites: (a) finely layered samples; (b) bauxite with porous, skeletal textures; (c) brecciated bauxite; (d) bauxite derived from weathered dolerite; e) hematite-rich, oxidized bauxite also derived from dolerite crops out in the northeastern and western parts of the plateau, whereas the dolerites occur in the eastern part along the Cogon River. These laterites are characterized by their thin layering, and the presence of structures and textures inherited from their parental rocks. They are porous and brownish-red to pinkish in colour. Bauxites developed on the argillites (Figure 7) commonly have thin, well-defined bedding (Figure 7a), whereas others have skeletal (Figure $7 b$ ) or porous textures (Figure 7c). These bauxites are texturally and structurally similar to the argillites and have inherited such features from them. Bauxites formed from dolerites in the plateau are distinguished by porous (Figure $7 \mathrm{~d}$ ) or massive textures (Figure 7e). In outcrops (rarely in samples) their natural division into shells is seen.

Many lateritic bauxites, particularly those derived from dolerite have abundant hematite which them a deep red color (Figure 7e).

Other bauxites are light brown with weak gelatinous and porous textures (Figure 8). These commonly have a kaolinite matrix in which crystals of gibbsite and hematite are embedded. A few grains of clastic quartz may also be present.

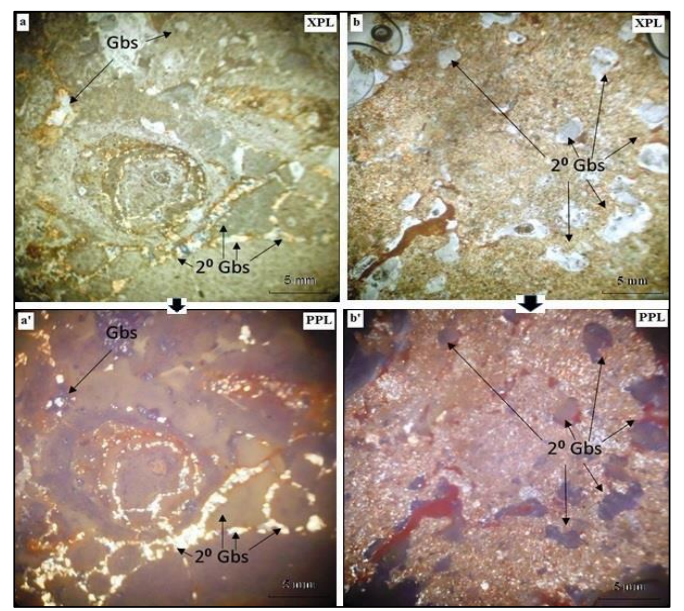

Figure 6. Photomicrographs of sediment-hosted bauxites: (a, a') oolites of gibbsite surrounded by hematite - white material is kaolinite; (b, b') massive sample with numerous grains of gibbsite (Gbs)
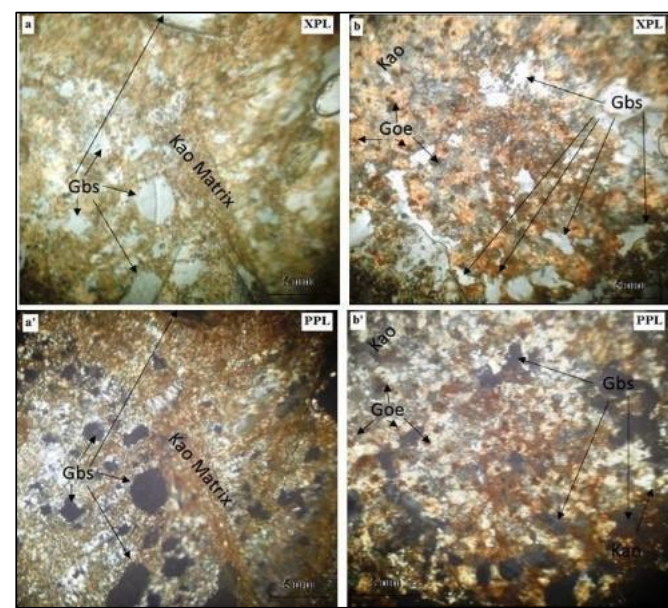

Figure 8. Photomicrographs of selected lateritic bauxite: (a, $\left.a^{\prime}\right)$ bauxite with a kaolinite matrix and porous texture, in which the pores are filled with gibbsite; $\left(b, b^{\prime}\right)$ granular or brecciated bauxitelwith kaolinite, gibbsite and geothite (Kao: kaolinite; He: hematite; Goe: goethite) 


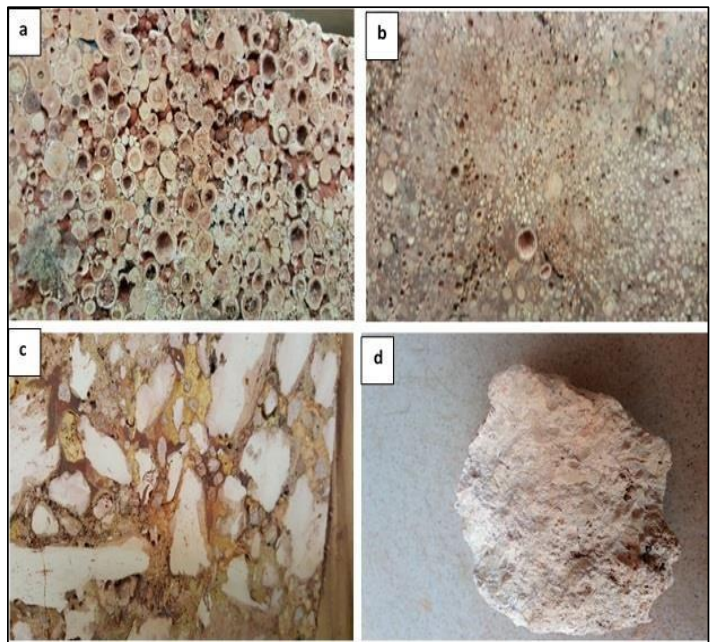

Figure 9. Photographs showing textures of chimogen bauxites of the Sangarédi deposit: (a) pisolitic bauxite; (b) Oolitic bauxite; (c) gelified bauxite with a mottled texture; (d) massive gelomorphic bauxite

\subsubsection{Chimogen bauxites alteration}

The development of bauxite is a long-term process involving both original formation and later enrichment in alumina. This secondary enrichment by gelatinous material produced 'chimogen' varieties, which have the highest $\mathrm{Al}_{2} \mathrm{O}_{3}$ contents in the Sangarédi deposit.

The uptake of large amounts of gelatinous material produces a variety of unusual textures ranging from pisolitic (Figure 9a) to oolitic (Figure 9b), and can yield mottled or loosely ribboned samples (Figure 9c). In case of intense gelling, the bauxites may develop massive aphanitic textures (Figure 9d).

In most case this overprinting obscures any textures inherited from the parental rocks. All of these gelomorphic teaxtures are well illustrated under the microscope (Figure 10). The pisolitic bauxite has a nodular texture, with pisolites and oolites of various shapes and sizes (Figure 10a). The oolites are composed dominantly of kaolinite with some gibbsite, hematite and diaspore. (Figure 10b).

\subsection{Mineralogy}

Four samples of Sangarédi bauxite were analysed by XRD using the Rietveld refinement technique to obtain semiquantitative mineralogical compositions; samples E-8 and E13 were analysed at ACME Laboratories, Vancouver, Canada (Figure 11) and samples E-05 and E-16 at the NGRL laboratory, Kadouna (Figure 12), Nigeria (The mineral abundances for samples E-8 and E-13, are given in Table 1 as the relative amounts of crystalline phases normalized to 100\%). These samples contain abundant structurally disordered gibbsite so the estimated amounts were obtained by allowing the atomic positions of the constituent atoms to vary slightly from the nominal.

Samples E-8 and E-13 have very similar compositions and consist chiefly of gibbsite, boehmite goethite and the two $\mathrm{TiO}_{2}$ phases, anatase and rutile, accompanied by small amounts of gibbsite, hematite, alumina-bearing goethite, kaolinite, and quartz; sample E-13 also contains small amounts of diaspore and dawsonite. Neither muscovite nor biotite were found in the samples.

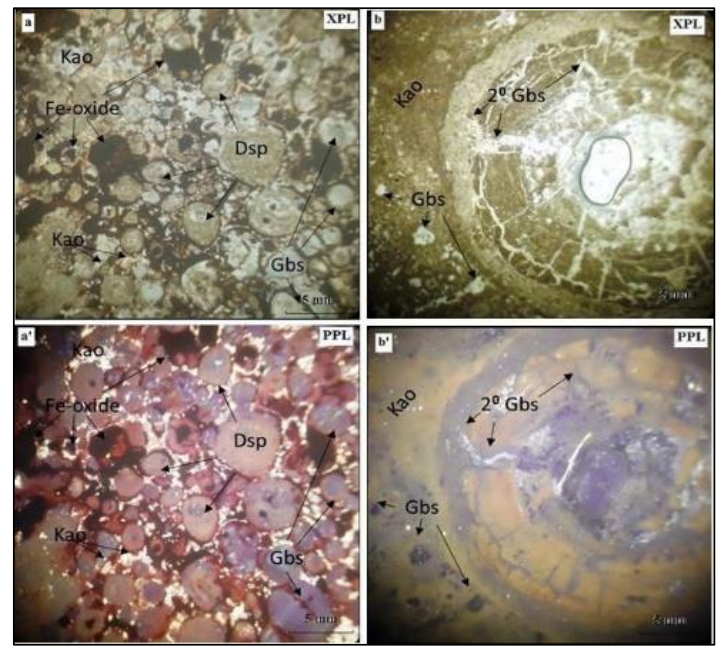

Figure 10. Photomicrographs of gelomorphic bauxites: (a,a') pisolites, with cores of gibbsite rimmed by hematite; (b, b') a spheroidal ooid with a white matrix filled with kaolinite. [Gbs: gibbsite; KaO: Fe-oxide (Hematite), Dsp: diaspore]
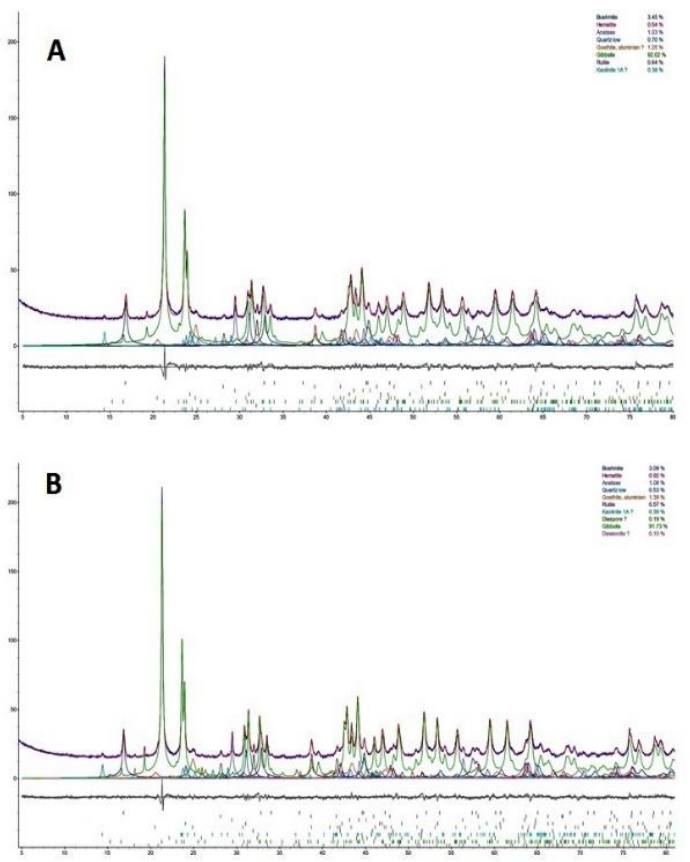

Figure 11. XRD pattern of samples E-08 and E-13 (ACME Laboratories, Vancouver, Canada)

Table 1. Results of semi-quantitative phase analysis (wt.\%) Estimated mineral abundance of the Sangarédi bauxite deposit by XRD

\begin{tabular}{cccc}
\hline Mineral & Ideal Formula & E08 & E13 \\
\hline Gibbsite & $\mathrm{Al}(\mathrm{OH})_{3}$ & 92 & 91.7 \\
Boehmite & $\gamma \mathrm{AlO} \cdot \mathrm{OH}$ & 3.5 & 3.1 \\
Goethite & $\alpha-\left(\mathrm{Fe} e_{3}+\mathrm{Al}\right) \mathrm{O}(\mathrm{OH})$ & 1.3 & 1.4 \\
Anatase & $\mathrm{TiO}_{2}$ & 1 & 1.1 \\
Hematite & $\alpha-\mathrm{Fe}_{2} \mathrm{O}_{3}$ & 0.5 & 0.9 \\
Kaolinite & $\mathrm{Al}_{2} \mathrm{Si}_{2} \mathrm{O}_{5}(\mathrm{OH})_{4}$ & 0.4 & 0.4 \\
Quartz & $\mathrm{SiO}_{2}$ & 0.7 & 0.5 \\
Rutile & $\mathrm{TiO}_{2}$ & 0.6 & 0.6 \\
Dawsonite & $\mathrm{NaAlCO}_{3}(\mathrm{OH})_{2}$ & - & 0.1 \\
Diaspore & $\alpha \mathrm{AlO} \cdot \mathrm{OH}$ & - & 0.2 \\
Total & \% & $\mathbf{1 0 0}$ & $\mathbf{1 0 0}$ \\
\hline
\end{tabular}




\subsection{Geochemistry}

\subsubsection{Major oxide compositions}

The major oxide compositions of 12 samples of bauxite from the Sangarédi deposit, including sediment-hosted, lateritic and chimogen varieties, are presented in Table 2 . They show $\mathrm{Al}_{2} \mathrm{O}_{3}$ contents ranging from 55.63 wt.\% to $68.92 \mathrm{wt} . \%$ with an average value of 61.25 wt. $\%$, whereas $\mathrm{SiO}_{2}$ ranges from $0.47 \mathrm{wt} . \%$ to $5.68 \mathrm{wt} . \%$ with a mean value of $1.34 \mathrm{wt} . \%$, $\mathrm{Fe}_{2} \mathrm{O}_{3}$ ranges from $1.46 \mathrm{wt} . \%$ to $8.89 \mathrm{wt} . \%$ with mean value of 3.99 wt. $\%$, and $\mathrm{TiO}_{2}$ ranges from 2.48 wt. $\%$ to 5.45 wt. $\%$ with a mean value of $3.91 \mathrm{wt} . \%$. Loss on ignition (LOI) ranges from $22.80 \mathrm{wt} . \%$ to $34.20 \mathrm{wt} \%$ with an average of $28.89 \mathrm{wt} . \%$. The alkali and alkali earth elements $\left(\mathrm{Na}_{2} \mathrm{O}, \mathrm{K} 2 \mathrm{O}, \mathrm{CaO}\right.$ and $\left.\mathrm{MgO}\right)$ have low values with averages lower than $0.2 \%$ wt. $\%$.

Correlation analysis shows positive but not significant correlations between $\mathrm{Al}_{2} \mathrm{O}_{3}$ and $\mathrm{TiO}_{2}(\mathrm{r}=0.127)$, positive correlations between $\mathrm{SiO}_{2}$ and $\mathrm{Al}_{2} \mathrm{O}_{3}(\mathrm{r}=0.357)$, and strong negative correlations between $\mathrm{Fe}_{2} \mathrm{O}_{3}$ and $\mathrm{Al}_{2} \mathrm{O}_{3}(\mathrm{r}=-0.723)$ in the Sangarédi bauxites (Table 4).

The triangular variation diagram of $\mathrm{Al}_{2} \mathrm{O}_{3}-\mathrm{SiO}_{2}-\mathrm{Fe}_{2} \mathrm{O}_{3}$ after Boulangé et al. [11] (Figure 13a), is commonly used for bauxite classification, and all our samples plot in the bauxite field, consistent with their very high alumina contents $\left(\mathrm{Al}_{2} \mathrm{O}_{3}\right.$ $=55.68 \mathrm{wt} . \%$ to $68.92 \mathrm{wt} . \%)$, very low $\mathrm{SiO}_{2}(0.47 \mathrm{wt} . \%$ to 5.68 wt $\%$ and $\mathrm{Fe}_{2} \mathrm{O}_{3}$ contents (1.46 wt.\% to $8.89 \mathrm{wt} \%$ ).

Geochemical paths of dismantlement of the original samples (Figure 13b), show that the Sangarédi bauxite formed by destruction of kaolinite and strong deferruginisation, indicating extreme lateritization (Figure 13c). This interpretation is supported by the chemical index of alteration, which ranges from 99.64 to 99.79 (Table 2).

\subsubsection{Trace elements}

Trace element data of samples from Sangarédi plateau are presented in Table 3. Zirconium has significantly high values ranging from $399 \mathrm{ppm}$ to $984 \mathrm{ppm}$ with an average of $693 \mathrm{ppm}$.
The bauxite samples from Sangarédi plateau Also have high values of $\mathrm{Sc}, \mathrm{Ga}, \mathrm{Nb}, \mathrm{Sr}$, Th, V, Zr, Y, La, as well as V, which ranges from 142 ppm-902 ppm with an average of 393 ppm and $\mathrm{Ce}$ that ranges from $148 \mathrm{ppm}-15 \mathrm{ppm}$ with an average of $69 \mathrm{ppm}$. Scandium, Ga, Nb, Sr, Th and Y are in the tens of parts per million range, generally between 13 to $65 \mathrm{ppm}$ with averages around 30 to $50 \mathrm{ppm}$. Correlation analysis shows that $\mathrm{TiO}_{2}$ and high field strength elements ( $\mathrm{Zr}, \mathrm{Hf}, \mathrm{Nb}$ and $\mathrm{Ta}$ ) display positive correlations (Table 4), as do $\mathrm{Zr}$ vs. Hf, Nb vs. $\mathrm{Ta}$ and $\mathrm{Lu}$ vs. Yb, (Figure 14). These results indicate that elements such as $\mathrm{Ti}, \mathrm{Zr}, \mathrm{Hf}, \mathrm{Nb}$ and $\mathrm{Ta}$ behaved in a similar manner during formation of the deposit. The ratio $\mathrm{Zr} / \mathrm{Ti}$ can also supply information about the chemical nature of parent rock. These two elements are concentrated in rutile and zircon and are considered to be relatively immobile.

\subsubsection{Rare earth elements}

Because REEs are relatively immobile during weathering, they are considered to be a useful guide to the protoliths of bauxites. the $\sum$ ree of sangarédi bauxite samples vary from 61 to $335 \mathrm{ppm}$ (Table 3). Interestingly, all of the analysed sangarédi bauxites have similar chondrite-normalizedree patterns showing flat hee, moderately negative eu anomalies and lree enrichment Figure 15. individual samples show varying degrees of enrichment with the chimogen varieties being the most aluminous.

The similarities of the REE patterns and Eu anomalies of the bauxites (sediment-hosted, lateritic and chimogen) from the Sangarédi deposit strongly suggest a common precursor, which appears to contradict the field observations, which suggest that the sediment-hosted and lateritic bauxites were derived from sedimentary rock and dolerites, respectively. The notable enrichment of all REE in the chimogen varieties suggests that these elements were more mobile during secondary enrichment. In the Sangarédi deposit, alumina has a low positive correlation with HREEs and a low negative correlation with LREEs (Table 4).
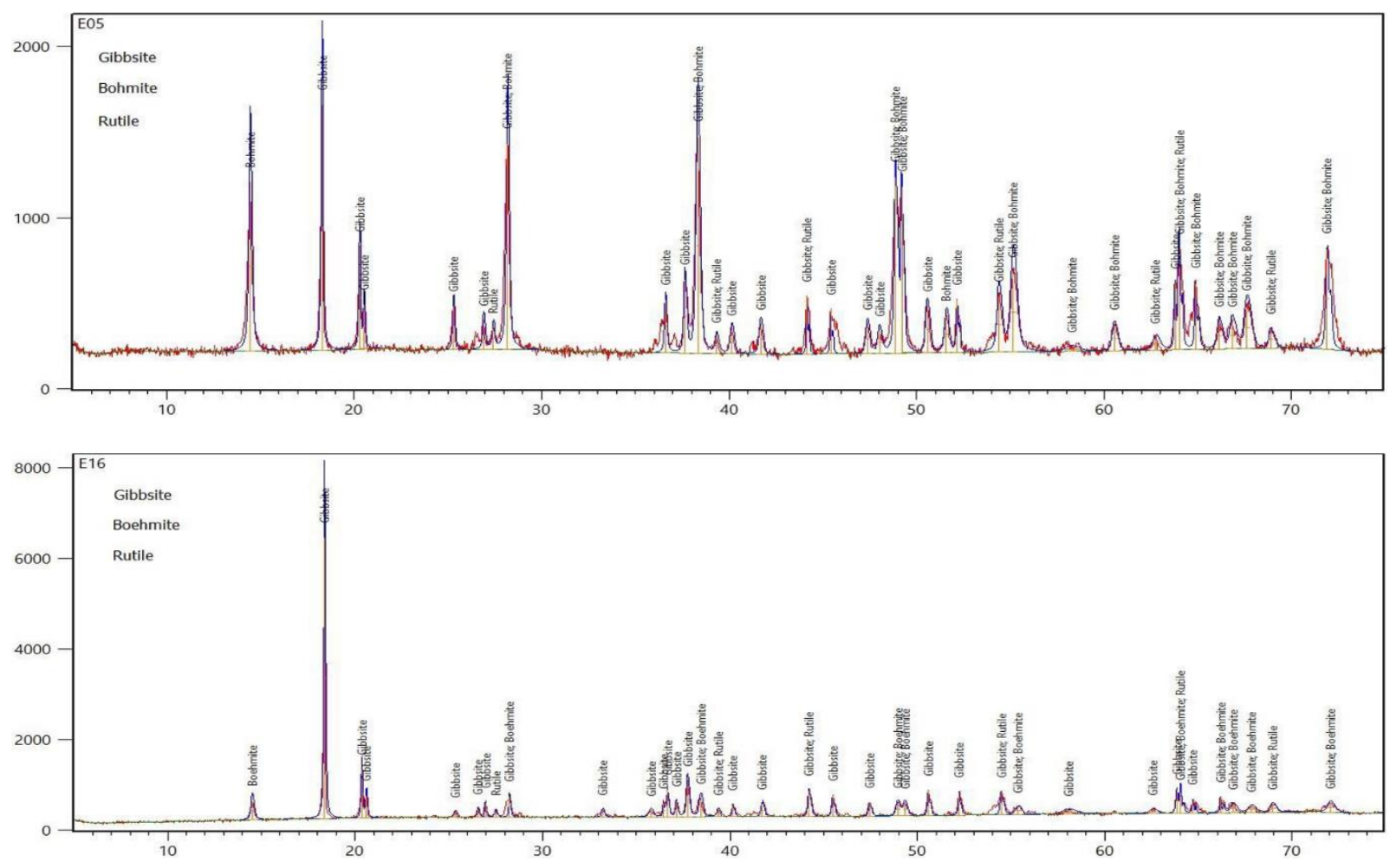

Figure 12. XRD pattern of samples E-05 and E-16 (NGRL Laboratory, Kadouna, Nigeria) 
Table 2. Major element compositions (wt.\%) of representative bauxite samples from the Sangarédi plateau

\begin{tabular}{|c|c|c|c|c|c|c|c|c|c|c|c|c|c|c|c|}
\hline TYPES & \multicolumn{15}{|c|}{ SEDIMENT-HOSTED BAUXITESLATERITIC BAUXITESCHIMOGEN BAUXITES } \\
\hline SAMPLES & E01 & E02 & E04 & E08 & E17 & E09 & E11 & E13 & E16 & E05 & E10 & E15 & MIN & MAX & MEAN \\
\hline $\mathrm{SiO}_{2}$ & 0.49 & 0.88 & 5.68 & 0.91 & 2.24 & 0.47 & 2.28 & 0.86 & 0.47 & 0.65 & 0.61 & 0.57 & 0.47 & 5.68 & 1.34 \\
\hline $\mathrm{Al}_{2} \mathrm{O}_{3}$ & 60.36 & 59.46 & 62.54 & 59.25 & 66.7 & 55.63 & 66.73 & 59.37 & 55.83 & 68.92 & 59.96 & 60.31 & 55.63 & 68.92 & 61.25 \\
\hline $\mathrm{Fe}_{2} \mathrm{O}_{3}$ & 2.06 & 3.23 & 3.62 & 3.26 & 2.32 & 8.89 & 2.29 & 3.35 & 8.89 & 1.46 & 6.56 & 1.99 & 1.46 & 8.89 & 3.99 \\
\hline MgO & 03 & 0.03 & 0 & 0.0 & 0.02 & 0.03 & 0.0 & 0.03 & 0.04 & 0.03 & 0.02 & 0.02 & 0.02 & 0.04 & 0.02 \\
\hline $\mathrm{Ca}$ & & & & 0.1 & & 0.0 & 0.0 & 0.0 & 0.03 & 0.16 & 0.03 & 0.18 & 0.03 & 0.18 & 0.09 \\
\hline $\mathrm{Na}_{2} \mathrm{O}$ & 0.01 & $<0.01$ & $<0.0$ & $<0.0$ & $<0.01$ & $<0.01$ & $<0.01$ & $<0.01$ & $<0.01$ & 0.01 & $<0.01$ & $<0.01$ & 0.01 & 0.01 & 0.01 \\
\hline $\mathbf{K}_{2} \mathbf{O}$ & 0.04 & 0.04 & 0.02 & 0.04 & $<0.01$ & 0.03 & $<0.01$ & 0.04 & 0.01 & 0.01 & 0.02 & 0.03 & 0.01 & 0.04 & 0.02 \\
\hline $\mathrm{TiO}_{2}$ & 2.49 & 2.61 & 4.61 & $2.5 \mathrm{C}$ & 4.33 & 5.45 & 4.33 & 2.68 & 5.39 & 5.19 & 4.86 & 2.48 & 2.48 & 5.45 & 3.91 \\
\hline $\mathbf{P}_{2} \mathrm{O}_{5}$ & 0.07 & 0.09 & 0.2 & 0.0 & 0.12 & 0.16 & 0.13 & 0.11 & 0.15 & 0.06 & 0.49 & 0.06 & 0.06 & 0.49 & 0.14 \\
\hline MnO & 0.01 & $<0.01$ & 0.02 & $<0.01$ & $<0.01$ & 0.02 & 0.01 & $<0.01$ & 0.02 & $<0.01$ & $<0.01$ & 0.01 & 0.01 & 0.02 & 0.01 \\
\hline $\mathrm{Cr}_{2} \mathrm{O}_{3}$ & 0.03 & 0.04 & 0.0 & 0.0 & 0.0 & 0.08 & 0.08 & 0.04 & 0.08 & 0.09 & 0.14 & 0.03 & 0.03 & 0.14 & 0.07 \\
\hline & & 33.3 & & 33. & 23.9 & 28.9 & 23.8 & 33.2 & 28.8 & 23.2 & 27 & 34.2 & 22.8 & 34.2 & 28.89 \\
\hline OTAL (WT\%) & 99.88 & 99.8 & 99.75 & 99.8 & 99.79 & 99.73 & 99.8 & 99.8 & 99.72 & 99.77 & 99.68 & 99.87 & 99.68 & 99.88 & 99.78 \\
\hline CIA & 99.65 & 99.8 & 99.79 & 99.78 & 99.82 & 99.87 & 99.84 & 99.78 & 99.91 & 99.74 & 99.9 & 99.64 & 99.64 & 99.91 & 99.79 \\
\hline
\end{tabular}

Table 3. Trace and REE geochemical analysis results (in ppm) in the representative bauxite samples from the Sangarédi plateau

\begin{tabular}{|c|c|c|c|c|c|c|c|c|c|c|c|c|c|}
\hline Samples & E01 & E02 & E04 & E05 & E08 & E09 & E10E11 & E13 & E15 & E16 E17 & MIN & MAX & MEAN \\
\hline $\mathrm{Ba}(\mathrm{ppm})$ & 14 & 59 & 43 & 10 & 60 & 7 & $\begin{array}{|ll|}6 & 13 \\
\end{array}$ & 58 & 13 & $\begin{array}{ll}7 & 15\end{array}$ & 6 & 60 & 25.4 \\
\hline $\mathbf{N i}$ & $<20$ & $<20$ & $<20$ & $<20$ & $<20$ & $<20$ & $<20<20$ & $<20$ & $<20$ & $<20<20$ & - & - & \\
\hline Sc & 13 & 15 & 53 & 28 & 15 & 35 & $65 \quad 37$ & 16 & 13 & $35 \quad 36$ & 13 & 65 & 30.1 \\
\hline $\mathbf{B e}$ & $<1$ & $<1$ & $<1$ & $<1$ & $<1$ & $<1$ & $<1<1$ & $<1$ & $<1$ & $<1$ & - & & \\
\hline Co & 1.6 & 0.9 & 4.6 & 0.6 & 1.1 & 3 & 2.13 .1 & 1 & 1.5 & $\begin{array}{ll}3.8 & 2.7\end{array}$ & 0.6 & 4.6 & 2.16 \\
\hline Cs & $<0.1$ & $<0.1$ & $<0.1$ & $<0.1$ & $<0.1$ & $<0.1$ & $<0.1<0.1$ & $<0.1$ & $<0.1$ & $<0.1<0.1$ & - & - & - \\
\hline Ga & 51.6 & 49 & 76.7 & 93.9 & 48.2 & 61 & 85.380 .4 & 50.3 & 49.6 & 62.579 .4 & 48.2 & 93.9 & 65 \\
\hline Hf & 11.2 & 16.6 & 17.7 & 26.5 & 16.7 & 20.2 & 22.219 .4 & 16.8 & 11.2 & 21.919 .6 & 11.2 & 26.5 & 18.3 \\
\hline $\mathrm{Nb}$ & 33.3 & 43.4 & 68.9 & 69.8 & 44.8 & 65.4 & 52.364 .6 & 45.7 & 34.9 & 71.165 & 33.3 & 71.1 & 54.9 \\
\hline $\mathbf{R b}$ & 1.1 & 1.5 & 0.5 & 0.5 & 1.5 & 0.6 & $\begin{array}{lll}0.7 & 0.4\end{array}$ & 1.5 & 1.2 & $0.6 \quad 0.4$ & 0.4 & 1.5 & 0.87 \\
\hline Sn & 5 & 6 & 7 & 11 & 6 & 7 & 98 & 7 & 4 & 8 & 4 & 11 & 7.2 \\
\hline $\mathrm{Sr}$ & 15.1 & 65.7 & 107 & 12.5 & 66.1 & 18 & 7.334 .1 & 72.3 & 15.8 & 19.432 .7 & 7.3 & 107. & 38.9 \\
\hline Ta & 2.4 & 3.1 & 4.5 & 4.8 & 3.3 & 4.1 & $2.4 \quad 4.1$ & 3.2 & 2.5 & 4.24 & 2.4 & 4.8 & 3.55 \\
\hline Th & 19.8 & 30.7 & 30.8 & 49.2 & 31.5 & 31 & 4133.1 & 32.3 & 21 & 33.634 .9 & 19.8 & 49.2 & 32.4 \\
\hline $\mathbf{U}$ & 3.5 & 5.5 & 6.2 & 6.4 & 5.4 & 6.9 & 8.16 .5 & 5.3 & 3.9 & 6.96 .3 & 3.5 & 8.1 & 5.9 \\
\hline V & 149 & 184 & 549 & 338 & 184 & 670 & 902374 & 198 & 142 & 663373 & 142 & 902 & 394 \\
\hline W & 2.9 & 3.7 & 6.9 & 6.1 & 3.8 & 5 & $5.5 \quad 6.1$ & 3.7 & 3.5 & $5.5 \quad 5.8$ & 2.9 & 6.9 & 4.9 \\
\hline $\mathbf{Z r}$ & 399 & 633 & 660 & 984 & 650 & 751 & 848718 & 647 & 420 & 848756 & 399 & 984 & 693 \\
\hline $\mathbf{Y}$ & 27 & 55.7 & 51.4 & 51.2 & 58.6 & 44.5 & 47.150 .3 & 59.2 & 28.6 & 48.151 & 27 & 59.2 & 47.7 \\
\hline La & 34.7 & 70.5 & 12.4 & 30.3 & 74.1 & 32 & $\begin{array}{ll}7 & 16.9\end{array}$ & 75.5 & 35.4 & 34.919 .5 & 7 & 75.5 & 36.9 \\
\hline $\mathrm{Ce}$ & 64 & 136 & 19.6 & 53.8 & 140.8 & 60.3 & 15.131 .51 & 147.6 & 65.6 & $65.9 \quad 32$ & 15.1 & 147. & 69.4 \\
\hline Pr & 5.58 & 14.05 & 52.43 & 5.02 & 14.73 & 6.28 & 1.563 .161 & 15.24 & 5.6 & 6.683 .42 & 1.56 & 15.24 & 6.9 \\
\hline Nd & 14.9 & 47.1 & 9.1 & 15.1 & 47.2 & 20.7 & 5.9 & 49.6 & 15.9 & $21 \quad 10.5$ & 5.9 & 49.6 & 22.2 \\
\hline Sm & 2.38 & 8.22 & 2.78 & 2.68 & 8.62 & 3.55 & 2.052 .4 & 8.52 & 2.57 & 3.732 .5 & 2.05 & 8.62 & 4.2 \\
\hline Eu & 0.57 & 1.67 & 0.73 & 0.71 & 1.71 & 0.79 & 0.590 .64 & 1.69 & 0.56 & 0.740 .68 & 0.56 & 1.71 & 0.92 \\
\hline Gd & 2.71 & 8.31 & 5.32 & 4.73 & 8.57 & 4.36 & 4.434 .66 & 8.59 & 2.95 & 4.774 .64 & 2.71 & 8.59 & 5.33 \\
\hline Tb & 0.61 & 1.55 & 1.19 & 1.09 & 1.59 & 0.96 & 1.081 .09 & 1.59 & 0.6 & 1.051 .08 & 0.6 & 1.59 & 1.12 \\
\hline Dy & 4.34 & 9.9 & 8.62 & 8.63 & 10.5 & 6.82 & 7.98 .091 & 10.36 & 4.44 & 7.558 .21 & 4.34 & 10.5 & 7.94 \\
\hline Но & 1 & 2.15 & 2.07 & 1.95 & 2.18 & 1.64 & 1.861 .87 & 2.21 & 0.99 & 1.721 .93 & 0.99 & 2.21 & 1.79 \\
\hline $\mathbf{E r}$ & 3.04 & 6.4 & 6.38 & 6.09 & 6.37 & 5.19 & 5.826 .3 & 6.39 & 3.35 & 5.536 .13 & 3.04 & 6.4 & 5.58 \\
\hline Tm & 0.44 & 0.89 & 0.98 & 0.95 & 0.92 & 0.76 & 0.90 .87 & 0.93 & 0.52 & 0.870 .89 & 0.44 & 0.98 & 0.82 \\
\hline Yb & 3.39 & 5.79 & 6.49 & 6.38 & 6.04 & 5.15 & 6.246 .2 & 6.26 & 3.49 & 5.826 .22 & 3.39 & 6.49 & 5.62 \\
\hline Lu & 0.5 & 0.87 & 1.03 & 1.01 & 0.9 & 0.84 & 11.01 & 0.94 & 0.56 & 0.910 .95 & 0.5 & 1.03 & 0.87 \\
\hline $\mathbf{E u} / \mathbf{E u} *$ & 0.69 & 0.62 & 0.58 & 0.61 & 0.61 & 0.62 & 0.60 .58 & 0.61 & 0.63 & 0.540 .61 & 0.54 & 0.69 & 0.60 \\
\hline DF & & & & & & & & & & & & & 169 \\
\hline
\end{tabular}

Table 4. Correlation coefficients R of REEs and some major and trace elements of the Sangarédi bauxite deposit

\begin{tabular}{ccccccccc}
\hline & $\mathrm{SiO}_{2}$ & $\mathrm{Al}_{2} \mathrm{O}_{3}$ & $\mathrm{Fe}_{2} \mathrm{O}_{3}$ & $\mathrm{TiO}_{2}$ & $\mathrm{P}_{2} \mathrm{O}_{5}$ & $\mathrm{Hf}$ & $\mathrm{Nb}$ & $\mathrm{Ta}$ \\
\hline $\mathbf{H f}$ & 0.00 & 0.30 & 0.34 & 0.82 & 0.35 & 1 & & \\
$\mathbf{N b}$ & 0.40 & 0.29 & 0.37 & 0.90 & 0.18 & 0.81 & 1 & \\
$\mathbf{T a}$ & 0.44 & 0.38 & 0.11 & 0.68 & -0.21 & 0.66 & 0.90 & 1 \\
$\mathbf{Z r}$ & -0.01 & 0.27 & 0.36 & 0.80 & 0.36 & 0.99 & 0.80 & 0.64 \\
$\mathbf{L a}$ & -0.39 & -0.37 & -0.13 & -0.66 & -0.51 & -0.31 & -0.50 & -0.24 \\
$\mathbf{C e}$ & -0.40 & -0.39 & -0.11 & -0.65 & -0.48 & -0.31 & -0.50 & -0.26 \\
$\mathbf{P r}$ & -0.35 & -0.39 & -0.07 & -0.61 & -0.43 & -0.26 & -0.45 & -0.21 \\
$\mathbf{N d}$ & -0.31 & -0.40 & -0.04 & -0.57 & -0.38 & -0.22 & -0.41 & -0.19 \\
$\mathbf{S m}$ & -0.20 & -0.36 & -0.04 & -0.54 & -0.30 & -0.18 & -0.35 & -0.15 \\
\hline
\end{tabular}




\begin{tabular}{lcccccccc} 
Eu & -0.14 & -0.29 & -0.08 & -0.52 & -0.26 & -0.13 & -0.32 & -0.12 \\
Gd & 0.02 & -0.16 & -0.04 & -0.34 & -0.12 & 0.06 & -0.10 & 0.04 \\
Tb & 0.12 & -0.05 & -0.001 & -0.15 & 0.007 & 0.25 & 0.08 & 0.18 \\
Dy & 0.20 & 0.11 & -0.02 & 0.01 & 0.05 & 0.43 & 0.26 & 0.34 \\
Ho & 0.32 & 0.16 & 0.04 & 0.17 & 0.16 & 0.53 & 0.41 & 0.44 \\
Er & 0.37 & 0.25 & 0.07 & 0.31 & 0.20 & 0.62 & 0.55 & 0.54 \\
Tm & 0.38 & 0.24 & 0.14 & 0.42 & 0.28 & 0.71 & 0.63 & 0.59 \\
Yb & 0.39 & 0.31 & 0.12 & 0.46 & 0.32 & 0.73 & 0.66 & 0.59 \\
Lu & 0.42 & 0.33 & 0.17 & 0.57 & 0.39 & 0.79 & 0.73 & 0.63 \\
\hline
\end{tabular}

\section{DISCUSSION}

\subsection{Genesis of Al-minerals}

The Sangarédi bauxite deposit differs somewhat in mineralogy and chemistry from the Balaya bauxite deposits in the Kindia region of Guinea as studied by Sidibe and Yalcin [10]. Minerals in the Sangarédi bauxite deposit are mainly gibbsite and boehmite, accompanied by small amounts of kaolinite, quartz, rutile, diaspore and dawsonite, whereas the Balaya deposits, contain gibbsite, anatase, hematite, rutile, aluminium-bearing goethite, kaolinite and diaspore [10]. Quartz and dawsonite are absent in the Balaya deposits [10]. Distribution histograms for the abundance of gibbsite, boehmite, goethite-aluminian, anatase and hematite in the Sangarédi bauxite samples, show that these minerals vary considerably in abundance (Figures 11 and 12). Gibbsite is the most abundant mineral in both the Sangarédi and Balaya deposits with average values of $92 \mathrm{vol} \%$, and $84 \mathrm{vol} \%$, respectively. Goethite is the dominant Fe-oxide Mineral in the Sangarédi bauxites. The relatively low abundance of quartz in the Sangarédi bauxite may be due to dissolution during weathering or to dilution by Fe- and Al-bearing minerals that introduced $\mathrm{Al}$ and $\mathrm{Fe}$ minerals from the overlying soil horizon $[12,13]$.

Goethite and hematite are both present in the Sangarédi samples and iron oxide is the first product of chemical weathering of biotite, although no biotite was found in these bauxites [14]. Hurst and Pickering [15] proposed that hematite is formed only in saturated oxic zones, where the groundwater contain chelating organics from bacteria. Bacteria are very abundant on Earth [16-19], and can drive low-temperature reactions that are not thermodynamically spontaneous, which would enhance weathering. Although goethite is present in the Sangarédi deposit (1.46 to $8.89 \mathrm{vol} \%$ ), it is significantly lower than in Balaya bauxite deposits 1.6 to 19.00 vol\% [10]. The abundant gibbsite and associated kaolinite in the Sangarédi deposit (Table 1) is thought to have formed through leaching of Si from kaolinite. Harder [20] proposed that the boehmite in these rocks may have formed by dehydration of gibbsite under the hot tropical climate.

Geochemical paths of dismantlement in the paper [21, 22], show that the Sangarédi bauxites formed by destruction of kaolinite and strong deferruginisation (Figure 13b). The major oxide values in the Sangarédi deposit correlate closely with the mineralogy; Aluminium is largely present as gibbsite, with smaller amounts in boehmite and diaspore; $\mathrm{Fe}$ occurs in goethite and hematite, whereas $\mathrm{Ti}$ is related to anatase and rutile; and $\mathrm{Si}$ to quartz and kaolinite. The triangular plot showing the degree of lateralization indicates that the Sangarédi bauxites were formed by with strong weathering [23] (Figure 13c). In the triangular variation diagram of $\mathrm{Al}_{2} \mathrm{O}_{3}-$ $\mathrm{SiO}_{2}-\mathrm{Fe}_{2} \mathrm{O}_{3}$ [11] (Figure 13a) all samples plot in the bauxite field, the high positive correlations between HREE, HFSE and $\mathrm{TiO}_{2}$ (Figure 14 and Table 4) indicate strong leaching of silica and alkaline earth elements leading to relative enrichment and residual enrichment of aluminium, iron and titanium during chemical weathering. The Fe-bearing minerals such as haematite, and goethite presumably formed under suitable Eh$\mathrm{Ph}$ conditions during the intense weathering [24].

The Chemical Index of Alteration: CIA = $\left[\frac{\mathrm{Al} 2 \mathrm{O} 3}{\mathrm{Al} 2 \mathrm{O} 3+\mathrm{CaO}+\mathrm{Na} 2 \mathrm{O}+\mathrm{K} 2 \mathrm{O}}\right] \times 100$, developed by Nesbitt and Young [25], is a useful means of quantifying the degree of weathering on sedimentary rocks. The CIA values of the Sangarédi bauxites are very high (99\%) somewhat comparable with, but higher than, the CIA value of river sediments $(96 \%)$ [15]. The low values of alkaline earth elements $(\mathrm{Na}, \mathrm{Ca}, \mathrm{Mg}$, $\mathrm{K})$ in the Sangarédi bauxite deposit are also indicative of extreme chemical weathering. The immobile elements ( $\mathrm{Al}$ and $\mathrm{Fe})$ preserved their enriched values during weathering.

The immobile elements ( $\mathrm{Al}$ and $\mathrm{Fe}$ ) preserved their enriched values during weathering. The extreme chemical weathering probably reflects reaction between precipitation and ground water, high temperatures and high rainfall. The presence of oolites and pisolites in the Sangarédi sediment-hosted bauxites probably reflects transport of parental sediment within a basin. The original parental rocks of the bauxite in the Sangarédi area were Palaeozoic argillites and dolerites [7]; According to Mamedov et al. [6], the younger parental rocks of the Sangarédi are siltstone, argillite and dolerite. The textures and structures of the lateritic bauxites strongly suggest derivation from the dolerites and argillites, currently exposed in the area.

We have shown above that $\mathrm{TiO}_{2}$ and high field strength elements $(\mathrm{Zr}, \mathrm{Hf}, \mathrm{Nb}$ and $\mathrm{Ta}$ ) of the bauxites correlate positively. $\mathrm{Nb}$ vs. Ta and $\mathrm{Zr}$ vs. Hf also have high positive correlations, which means that elements such as Ti and HFSE ( $\mathrm{Zr}, \mathrm{Hf}, \mathrm{Nb}$ and $\mathrm{Ta}$ ) behaved similarly during deep weathering and that they were stable during formation of the Sangarédi bauxites.

Based on textural and structural relationship, Sangarédi plateau lateritic bauxites originated from the underlying argillites of the Devonian faro formation and dolerites of the Mesozoic. Sangarédi sedimentary bauxites originated from accumulated sediments of the Sangarédi Serie, there is evidence of transportation of bauxite sediments based on the presence of pisoid and ooid forms. Significant weathering of source rocks is probable based on the CIA of river sediments. The $\mathrm{Al}_{2} \mathrm{O}_{3}-\mathrm{SiO}_{2}-\mathrm{Fe}_{2} \mathrm{O}_{3}$ geochemical paths and immobile element ratios ( $\mathrm{Zr}$ vs. Hf, Ntheb vs. Ta, and $\mathrm{Yb}$ vs. $\mathrm{Lu}$ ) $\mathrm{Al}_{2} \mathrm{O}_{3}$ of the Sangarédi lateritic bauxites show that these deposits probably originated from the weathering of kaolinite by strong lateritisation, suggesting a two-step process. The Sangarédi chimogen bauxites were further formed by recrystallization and late-stage enrichment in alumina. 

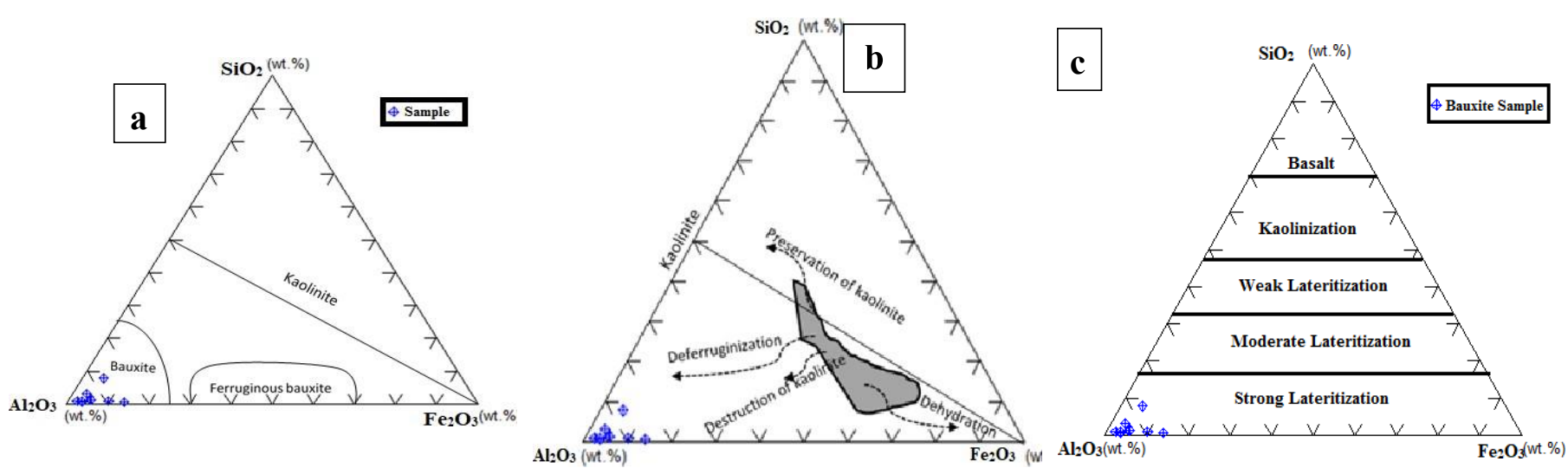

Figure 13. a: $\mathrm{Al}_{2} \mathrm{O}_{3}-\mathrm{SiO}_{2}-\mathrm{Fe}_{2} \mathrm{O}_{3} \mathrm{~T}$ triangular plot showing bauxite classification after Boulangé et al. [11]; b: Geochemical paths of dismantlement according to Beauvais [26] indicating various trends followed during the formation of bauxite depending upon whether quartz is present or absent in the soft microgranular matrix; here the shaded portion shows data of ferruginous cuirasses [21, 22]; $\mathrm{c}$ : The $\mathrm{Al}_{2} \mathrm{O}_{3}-\mathrm{SiO}_{2}-\mathrm{Fe}_{2} \mathrm{O}_{3 \mathrm{t}}$ triangular plot showing degrees of lateritisation by Schellman [23].

Table 5. Comparison of the Sangarédi bauxite deposit with others in the world

\begin{tabular}{|c|c|c|c|}
\hline Bauxite deposits & Authors & $\mathrm{Al}_{2} \mathrm{O}_{3}(\mathrm{wt} \%) \mathrm{SiO}_{2}(\mathrm{wt} \%) \mathrm{Fe}_{2} \mathrm{O}_{3}(\mathrm{wt} \%)$ & $\begin{array}{c}\text { Dominant } \\
\text { mineral }\end{array}$ \\
\hline Sangarédi deposit, Guinea & Present work & $(55.63-68.92)(0.47-5.68) \quad(1.46-8.89)$ & $\begin{array}{c}\text { Gibbsite, } \\
\text { Average: } 91.85 \%\end{array}$ \\
\hline $\begin{array}{l}\text { Balaya deposits, Kindia, } \\
\text { Guinea }\end{array}$ & \multicolumn{2}{|c|}{ Sidibe and Yalcin $[10](49.70-61.00)(0.30-5.00)(1.60-19.00)$} & $\begin{array}{l}\text { Gibbsite, } \\
\text { Average: } 83.9 \%\end{array}$ \\
\hline Fria deposits, Fria, Guinea & Boulangé et al. [11] & $(56.00-60.00)(1.00-12.00)(1.00-8.00)$ & $\begin{array}{l}\text { Gibbsite, } \\
\text { Average: } 76 \%\end{array}$ \\
\hline Foumban's bauxites, West Cameroon & Njoya et al. [27] & $(46.15-59.27)(2.18-18.79)(4.53-21.20)$ & $\begin{array}{c}\text { Gibbsite, } \\
\text { Average: } 76.36 \%\end{array}$ \\
\hline $\begin{array}{l}\text { Bolkardaği bauxite } \\
\text { deposits, Turkey }\end{array}$ & Hanilci, N. [28] & $(43.00-60.1)(1.20-21.20)(10.0-27.10)$ & $\begin{array}{c}\text { Diaspore } \\
\text { Average: NA }\end{array}$ \\
\hline Bauxite deposit of Barro Alto, Central Bra & IDe Oliveira et al., [29] & $(49.74-62.00)(0.45-22.62)(1.99-3.69)$ & $\begin{array}{c}\text { Gibbsite } \\
\text { Average: NA }\end{array}$ \\
\hline Darling Range, Western Australia & Anand et al. [13] & Average 34.5 Average 21 Average 21 & $\begin{array}{c}\text { Gibbsite } \\
\text { Average: NA }\end{array}$ \\
\hline
\end{tabular}

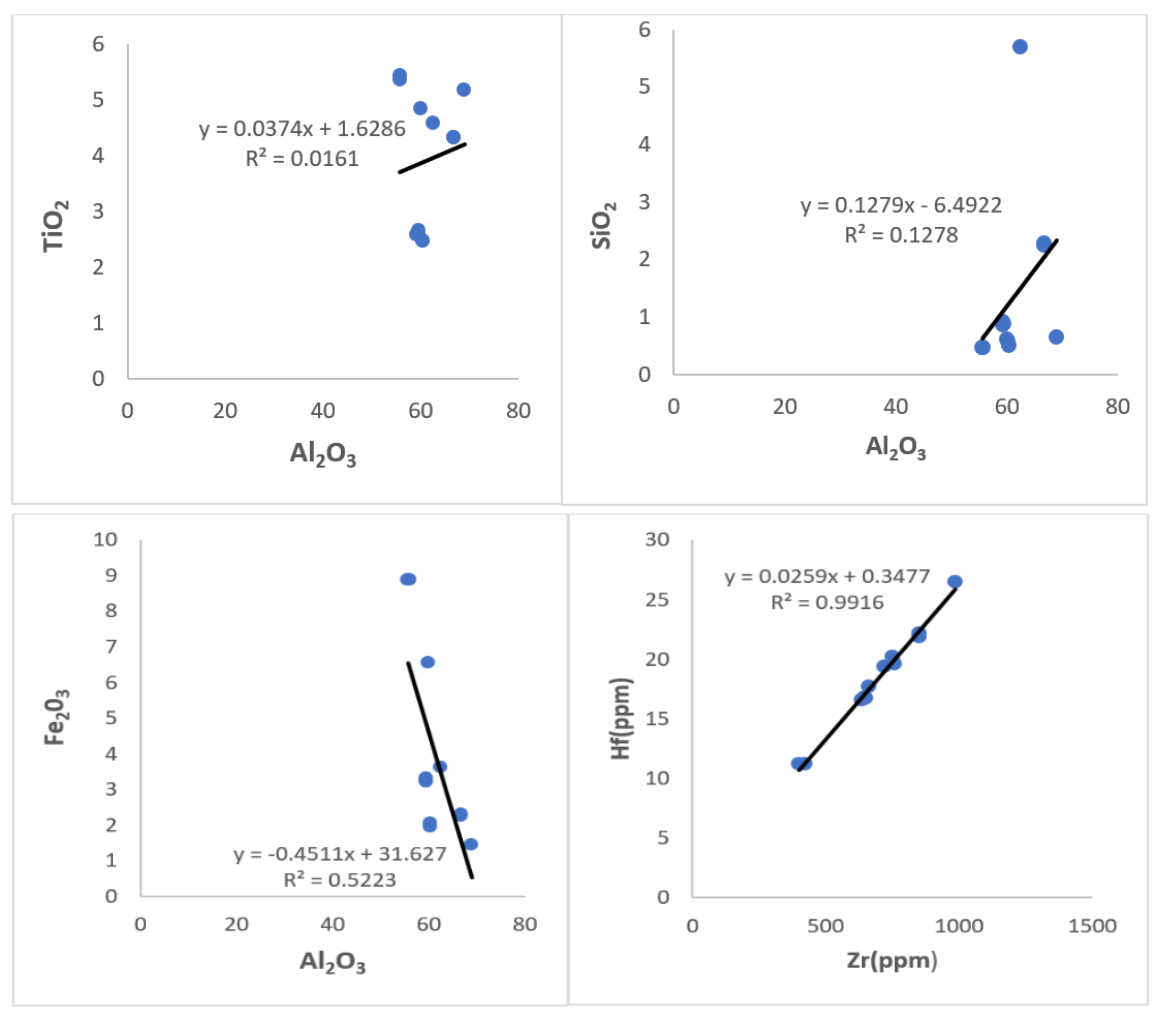




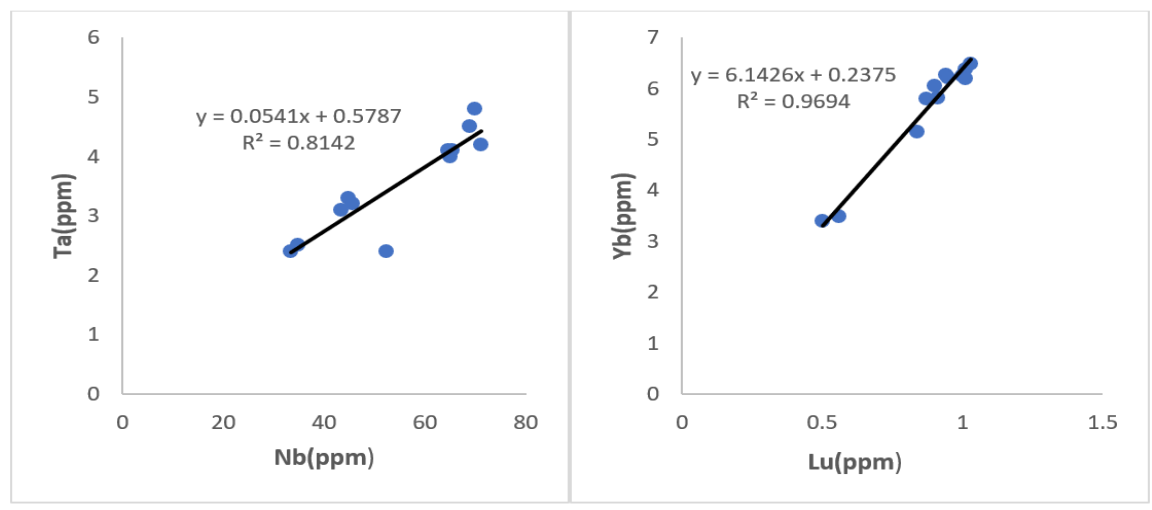

Figure 14. Binary diagrams showing correlations between (a) $\mathrm{Al}_{2} \mathrm{O}_{3}$ and $\mathrm{TiO}_{2}$, (b) $\mathrm{Al}_{2} \mathrm{O}_{3}$ and $\mathrm{SiO}_{2}$, (c) $\mathrm{Al}_{2} \mathrm{O}_{3}$ and $\mathrm{Fe}_{2} \mathrm{O}_{3}$, (d) $\mathrm{Zr}$ and $\mathrm{Hf}$; (e) $\mathrm{Nb}$ and $\mathrm{Ta}$, and (f) Lu and $\mathrm{Yb}$ for the Sangarédi bauxite deposit

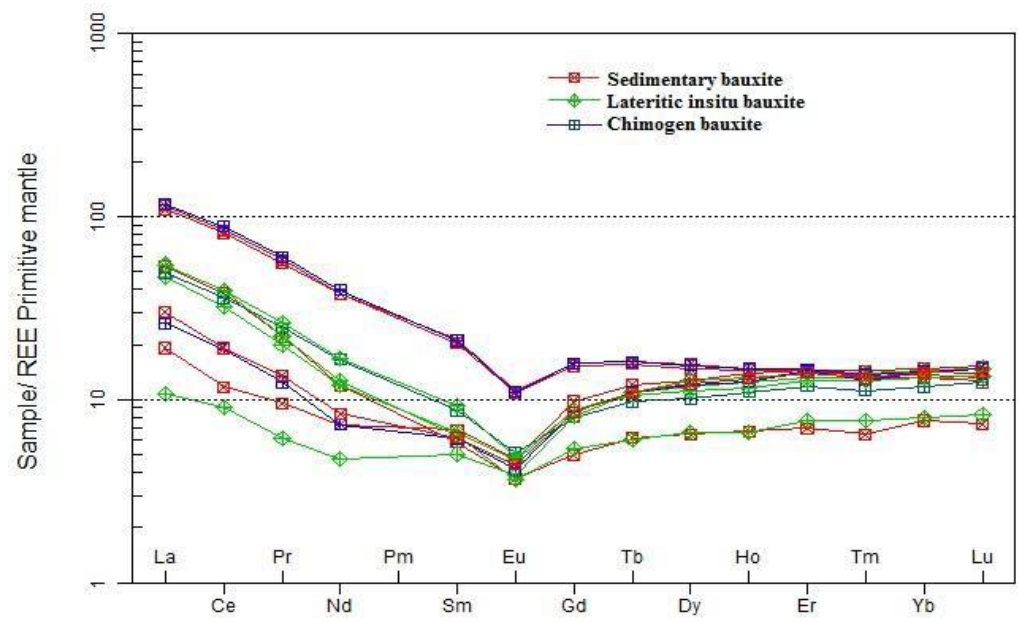

Figure 15. Chondrite-normalized patterns of the bauxites of the Sangarédi deposit. Normalizing values are after Sun and McDonough [30]

\subsection{Summary of the Sangarédi bauxite deposits}

The geochemical setting of the Sangarédi bauxite deposits involved a tropical climate, rich vegetation, and high biological activity within sediments containing abundant organic matter being deficient in oxygen. Iron was initially present in its ferrous and leached away by ground water [6]. The bedrocks existing within the Sangarédi plateau are argillite, dolerite and Cenozoic sediments [6], thus overall deposit contains many polygenetic bauxites. A distinct correlation exists between genesis of bauxites and their quality. This is reflected not only in the alumina content but also abundances of gibbsite and goethite in the bauxites.

\subsubsection{Sediment-hosted bauxites}

Sediment-hosted bauxites developed on alluvial and alluvio-lacustrine sediments deposited in Mid-Miocene (samples E01, E02, E04, E08 and E17). Thi bauxite is characterized by very low silica and very high alumina contents (Table 2); the iron content is low. Whatever iron the sediments originally had was probably leached by circulating groundwater. Circulation of groundwater in these sediments was facilitated by the abundance of gravels and conglomerates. The sediment-hosted bauxites are uniformly high-quality deposits are with high alumina contents (average of $61.5 \mathrm{wt} \%$ ), low silica content and iron-oxide contents (average values 1.38 wt $\%$ and $3.71 \%$, respectively) (Table 2 ).

\subsubsection{Lateritic bauxites}

In-situ lateritic bauxites formed by intense weathering of pre-existing argillites and dolerites in the Sangarédi plateau. Bauxites derived from the dolerites have higher $\mathrm{Fe}_{2} \mathrm{O}_{3}$ and silica contents (average $7.04 \mathrm{wt} \%$ and lower silica contents (average $0.65 \mathrm{wt} \%$ than those formed from the argillites. However, as expected, the alumina contents of the bauxites formed from the argillites have significantly higher Al2O3 contents (e.g. samples E09, E11, E13 and E16 (Table 2).

\subsubsection{Chimogen bauxites}

This genetic type was formed by recrystallization of bauxite already formed from one of the two previous genetic types (laterite or sediment-hosted), thus undergoing additional enrichment with alumina. Chimogen bauxites found within the Sangarédi plateau, are characterized by very high contents of alumina and very low contents of Fe-oxides and silica, as shown by samples E05, E10 and E15 (Table 2); Chimogen bauxites have pisolitic, oolitic, gelified and gelomorph textures. The chemical compositions of the chimogen bauxites with gelomorph texture in Sangarédi deposit are very high in alumina (up to $69 \mathrm{wt} \%$ ), making it one of the richest deposits in the world [1]. In our study, we compared the Sangarédi bauxite deposit to those in other parts of Guinea and other countries and confirmed that it has the highest quality of known bauxites in Guinea and other parts of the world (Table 5; Figure 16). 


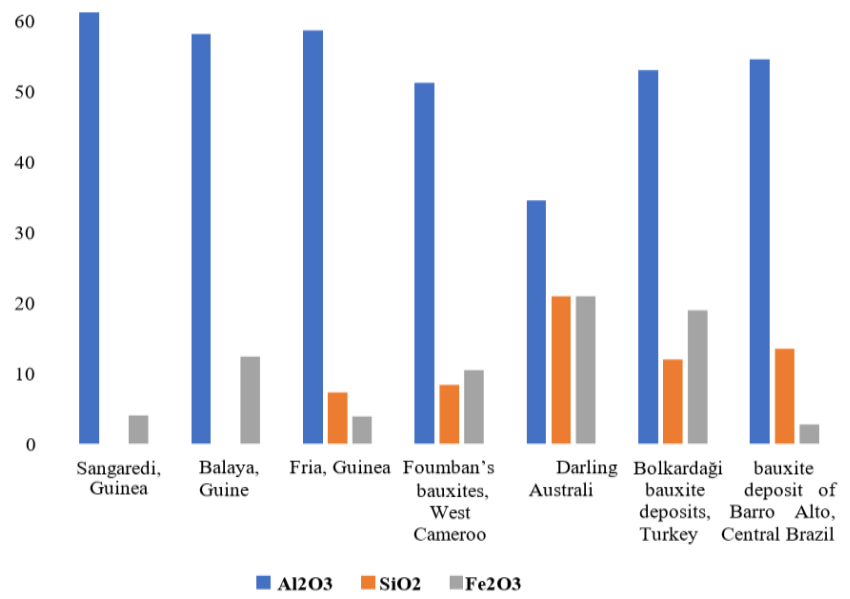

Figure 16. Histogram comparing the Sangarédi deposit with other deposits in Guinea and elsewhere in the world (Present work and after Sidibe and Yalcin [10]; Boulangé et al. [11]; Njoya et al. [27]; Hanilci [28]; De Oliveira et al. [29]; and Anand et al. [13]

\section{CONCLUSIONS AND RECOMMENDATIONS}

The bauxites of the Sangarédi deposit were formed by laterization of various parental rocks, including argillites, dolerites and marine sediments. Some of these were later modified by the diagenetic processes to form high-alumina chimogen varieties.

XRD analysis and thin section observations show that all of the bauxites consist chiefly of gibbsite (91 vol.\%), with lesser amounts of boehmite and aluminous goethite. Anatase, rutile, diaspore, kaolinite, hematite, quartz and dawsonite are minor minerals. Geochemically, the bauxites consist primarily of $\mathrm{Al}_{2} \mathrm{O}_{3}$ (up to $68 \mathrm{wt} \%$ ) with small amounts of $\mathrm{Fe}_{2} \mathrm{O}_{3}, \mathrm{TiO}_{2}$ and $\mathrm{SiO}_{2}$ and significant values of $\mathrm{Sc}, \mathrm{Ga}, \mathrm{Nb}, \mathrm{Sr}, \mathrm{Th}, \mathrm{V}, \mathrm{Zr}, \mathrm{Y}, \mathrm{La}$ and $\mathrm{Ce}$. High field strength elements ( $\mathrm{Zr}, \mathrm{Hf}, \mathrm{Nb}, \mathrm{Ta}$, Th, and $\mathrm{U})$ were enriched during the bauxitization.Correlations reveal that elements such as Ti and HFSE ( $\mathrm{Zr}, \mathrm{Hf}, \mathrm{Nb}$ and $\mathrm{Ta}$ ) behaved in a similar fashion during formation of the Sangarédi deposit. Interestingly, all the Sangarédi bauxites have similar geochemical characteristic regardless of their Textural and structural features of plateau lateritic bauxite show that they originated by intense weathering of kaolinite from argillites, dolerites and marine sediments of the Sangarédi Series. The chimogen bauxites were formed by secondary fertilization of alumina during diagenetic modification.

The Sangarédi bauxites, particularly the chimogen varieties are the richest in alumina and have the highest quality of known deposits elsewhere in Guinea and other parts of the world. To complete this study, future researches should be focused on the investigation of the parent rock to determinate the age of the host rock and the mineralization age.

\section{ACKNOWLEDGEMENTS}

The authors thank the Africa Union for the Scholarship (Ref: PAULESI/Adms.2017) awarded to the first author through Pan African University. The readability of the document has been improved by corrections from Prof. Paul P. Robinson and Prof. G.O. Adeyemi. The authors also thank Prof. P.P. Robinson and Prof. G.O. Adeyemi for their contribution. The first author would like to thank the Company of Bauxites of Guinea (CBG) for accepting his research internship at the company. He also expresses his gratitude to Mamadou Condé and all the geologists of the Sangarédi mine who facilitated samples collection in the field.

Funding: This study was funded by the Africa Union, through the Pan African University Scholarship (Ref: PAULESI/ Adms. 2017) awarded to the first author.

\section{REFERENCES}

[1] Mamedov, V.I., Bouféév, Y.V., Nikitine, Y.A. (2010). Géologie de la République de Guinée. Min. des Mines et de la Géologie . GEOPROSPECTS Ltd, Aquarel, p314.

[2] Bushinskiy (1975). Geologiya Boksitov [Geology of bauxite] (2nd ed.): Moscow, Izdatel'stvo, Nedra, p416.

[3] Schmidt, F. (1984). Geology of recent/potential bauxite producing areas in Sierra Leone and in the Peoples' Revolutionary Republic of Guinea (West Africa). In Jacob, Leonard, Jr., ed., Bauxite [Bauxite Symposium, Los Angeles, Calif., 1984, Proceedings]: New York, American Institute of Mining, Metallurgical and Petroleum Engineers, pp. 486-499.

[4] Akayemov, S.T. (1975). Litologiyai genezis boksitov Sangarédi (Zapadnaya Afrika) [Lithology and genesis of Sangarédi bauxite, western Africa], in Bushinskiy, G.L, ed., Problemy genezisa boksitov [Problems of bauxite genesis]: Moscow, Izdatel'stvo Nauka, pp. 235-246.

[5] Patterson, S.H., Kurtz, H.F., Olson, J.C., Neeley, C.L. (1986). World Bauxite Resources. U.S. Geological Survey. Professional Paper no. 1076B. U.S. Government Printing Office, Washington, DC.

[6] Mamedov, V.I., Chausov, A.A., Kanishev, A.I. (2011). Formation stages of the unique Sangarédi bauxitebearing group, Futa Jallon-Mandingo province, West Africa. Geology of Ore Deposits, 53(3): 177-201. https://doi.org/10.1134/S1075701511030044

[7] Zhang, R., Gong, E., Wang, G., Peng, W. (2018). Mineralization Patterns and Conditions of Lateritic Gibbsite Bauxite in Guinea. Advances in Geoscience, 2(1).

[8] Chu, X.C. (1982). African Geology [M]. Institute of Geology Chinese Academy of Geological Science.

[9] Mamedov, V.I., BouféévY, V., NikitineY, A., Mamedov, A.I. (2010). Banque des données des gisements et indices de minéraux utiles. Min. des Mines et de la Géologie Rép. de Guinée. GEOPROSPECTS Ltd.; Univ.e d'Etat de Moscou Lomonossov (Fac. Géol.) - Conakry - Moscou, Aquarel, p264.

[10] Sidibe, M., Yalcin, M.G. (2019). Petrography, mineralogy, geochemistry and genesis of the Balaya bauxite deposits in Kindia region, Maritime Guinea, West Africa. Journal of African Earth Sciences, 149: 348-366. https://doi.org/10.1016/j.jafrearsci.2018.08.017

[11] Boulangé, B., Bouzat, G., Pouliquen, M. (1996). Mineralogical and geochemical characteristics of two bauxitic profiles, Fria, Guinea Republic. Mineralium Deposita, 31(5): 432-438. https://doi.org/10.1007/BF00189190

[12] Loughnan, F.C., Sadleir, S.B. (1984). Geology of established bauxite-producing areas in Australia. Bauxite, 436-450. 
[13] Anand, R.R., Gilkes, R.J., Roach, G.I.D. (1991). Geochemical and mineralogical characteristics of bauxites, Darling Range, Western Australia. Applied Geochemistry, 6(3): 233-248 https://doi.org/10.1016/0883-2927(91)90001-6

[14] Farmer, V.C, Wilson, M.J. (1970). Experimental conversion of biotite to hydrobiotite. Nature, 226: 841842.

[15] Hurst, V., Pickering, S. (1997). Origin and classification of coastal plain kaolin, southeastern USA, and the role of groundwater and microbial action. Clays and Clay Minerals, 45: 274-285.

[16] Margulis, L., Sagan, D. (1986). Microcosmos: Four Billion Years of Evolution from Our Microbial Ancestors. New York: Summit Books, p301.

[17] Gould, S. (1996). Our life on the earth's surface, based on solar energy and photosynthesis, may be the exception rather than the rule. Nat. History, 105(3): 20-23.

[18] Brown, A., Sheriff, B. (1996) Geomicrobiology Symposium at Winnipeg 96: Geol. Assoc. Canada and Miner Assoc. Canada joint meeting. Program and abstract. p. A13.

[19] Ayorinde, A.O. (2011). Mineralogy and geochemistry of the bauxite deposits (Cretaceous). In Wilkinson County, Georgia. Geosciences Theses, Paper 30. Georgia State University.

[20] Harder, E.C. (1952). Examples of bauxite deposits illustrating variations in origin. Problem of Clay and Laterite Genesis, AIME Symposium, St. Louis, pp. 3564.

[21] Tardy, Y. (1997). Petrology of Laterites and Tropical Soils. Balkema Publishers, Rotterdam.

[22] Meshram, R., Randive, K.R. (2011), Geochemical study of laterites of the Jamnagar district, Gujarat, India: Implications on parent rock, mineralogy and tectonics. J. Asian Earth Sci., 42 (6): 1271-1287.

[23] Schellmann, W. (1986). A new definition of laterite.
Memoir Geol. Survey India, 120: 1-7.

[24] Gu, J., Huang, Z., Fan, H., Jin, Z., Yan, Z., Zhang, J. (2013). Mineralogy, geochemistry, and genesis of lateritic bauxite deposits in the Wuchuan-Zheng'anDaozhen area, Northern Guizhou Province, China. J. Geochem. $\quad$ Explor., 130: 44-59. https://doi.org/10.1016/j.gexplo.2013.03.003

[25] Nesbitt, E., Young, G. (1982). Early Proterozoic climates and plate motions inferred from major element chemistry of lutites. Nature, 299: 715-717. https://doi.org/10.1038/299715a0

[26] Beauvais, A. (1991). Palaeoclimats et dynamique d'un paysage cuirasee du centrafreque: Morphologie, petrologie et geochimie. Thesis. University Poitiers, p315.

[27] Njoya, D., Njoya, A., Ngueteu, A.K., Tchuindjang, Y.D., Nkoumbou, C. (2017). Caractérisation chimique et minéralogique de quelques indices de bauxite de Foumban (Ouest-Cameroun). International Journal of Biological and Chemical Sciences, 11(1): 444-452. https://doi.org/10.4314/ijbcs.v11i1.35

[28] Hanilci, N. (2013). Geological and geochemical evolution of the Bolkardagi bauxite deposits, Karaman, Turkey: Transformation from shale to bauxite. J. Geochem. $\quad$ Explor., 133: 118-137. https://doi.org/10.1016/j.gexplo.2013.04.004

[29] De Oliveira, F.S., Varajão, A.F.D.C., Varajão, C.A.C., Boulangé, B., Soares, C.C.V. (2013). Mineralogical, micromorphological and geochemical evolution of the facies from the bauxite deposit of Barro Alto, Central Brazil. Catena, 105: 29-39. https://doi.org/10.1016/j.catena.2013.01.004

[30] Sun, W.D., McDonough, W.F. (1989). Chemical and isotopic systematics of oceanic basalts: Implications for mantle composition and processes. Geological Society, 42(1):

313-345. http://dx.doi.org/10.1144/GSL.SP.1989.042.01.19 